\title{
DIFERENCIJALNA DIJAGNOSTIKA POREMEĆAJA TEČNOSTI GOVORA
}

\author{
ANA ANDRIJOLIĆ I ANA LEKO KRHEN \\ Sveučilište u Zagrebu, Edukacijsko-rehabilitacijski fakultet, Odsjek za logopediju, \\ Borongajska cesta 83f, 10 000, Zagreb, ana.andrijolic@gmail.com
}

Primljeno: 26.5.2016.

Pregledni rad

Prihvaćeno: 15.8.2016.

UDK: 616.89-008.434

Sažetak: Diferencijalna logopedska dijagnostika pretpostavlja prepoznavanje nekog poremećaja i njegovo razlučivanje od drugih poremećaja koji imaju neke zajedničke simptome. U području poremećaja tečnosti govora, netečnosti predstavljaju zajednički simptom koji se može pojaviti kao dio kliničke slike različitih razvojnih i stečenih poremećaja kao što su razvojno mucanje, neurogeno mucanje, psihogeno mucanje, sindrom brzopletosti, afazija, dizartrija, apraksija, palilalija, Parkinsonova bolest te različiti genetski sindromi poput Downovog sindroma, Fragilnog X sindroma, Prader-Willijevog sindroma, Touretteovog sindroma, Neurofibromatoze tip I i Turnerovog sindroma.

Na temelju pregleda novije literature, u ovom radu prikazan je opis navedenih poremećaja tečnosti govora, njihova opća $i$ specifična simptomatologija te su naglašeni diferencijalno dijagnostički kriteriji. Budući da diferencijalna dijagnostika poremećaja tečnosti još uvijek predstavlja veliki izazov u području logopedije, ovaj rad može poslužiti kliničarima kao orijentir u dijagnostičkom postupku. Različiti poremećaji zahtijevaju različite terapijske postupke stoga je postavljanje točne dijagnoze temelj planiranja $i$ provođenja uspješne intervencije. Istraživanja poremećaja tečnosti govora većinom su metodološki neujednačena i veliki broj njih čine studije slučajeva. Buduća istraživanja u ovom području trebaju obuhvatiti veći broj ispitanika, detaljno analizirati govorne i negovorne karakeristike kroz različite govorne zadatke kako bi rezultati istraživanja mogli imati teorijsku i kliničku primjenu.

Ključne riječi: diferencijalna dijagnostika, poremećaji tečnosti govora, razvojni poremećaji, stečeni poremećaji

\section{UVOD}

Diferencijalna logopedska dijagnostika pretpostavlja prepoznavanje nekog poremećaja i njegovo razlučivanje od drugih poremećaja koji imaju neke zajedničke simptome (Sardelić i sur., 2001). Netečnosti u govoru temeljni su simptom mucanja. Isto tako, netečnosti se pojavljuju i kao prvi simptom brojnih razvojnih i stečenih poremećaja komunikacije. Poremećaji i oboljenja kod kojih se javljaju netečnosti u govoru su razvojno mucanje, neurogeno mucanje, psihogeno mucanje, sindrom brzopletosti, afazija, dizartrija, apraksija, palilalija, Parkinsonova bolest te različiti genetski sindromi kao što su Downov sindrom, Fragilni X sindrom, Prader-Willijev sindrom, Touretteov sindrom, Neurofibromatoza tip I i Turnerov sindrom.

Budući da se diferencijalna dijagnostika poremećaja tečnosti govora uglavnom temelji na analiziranju govora i govornih netečnosti, potrebno je naglasiti važnost razlikovanja mucajućih netečnosti (netečnosti unutar riječi, netečnosti poput mucanja, manje tipične netečnosti) i običnih netečnosti (netečnosti između riječi, druge netečnosti, normalne vrste netečnosti, više tipične netečnosti) (Yaruss, 1997; prema Manning, 2010). Netečnosti kao što su ponavljanja jednosložnih riječi, slogova i glasova, produžavanja glasova, napete pauze i blokade, karakteriziraju govor osoba koje mucaju, ali se povremeno javljaju i u govoru tečnih osoba. U nastavku ovog rada za navedene netečnosti u govoru koristit će se termin „mucajuće netečnosti“'. Suprotno tome, ponavljanja višesložnih riječi, fraza, ispravljanja, nedovršeni iskazi, umetanja i oklijevanja su netečnosti koje se često javljaju u govoru svih govornika ali i u govoru osoba koje mucaju. Za ovu skupinu netečnosti u nastavku rada koristit će se termin „obične netečnosti“".

U području poremećaja tečnosti govora, diferencijalna dijagnostika još uvijek predstavlja izazov jer ne postoje uvijek dostatni objektivni krite- 
riji za postavljanje dijagnoze. Međutim, s povećanom svjesnošću o nekim poremećajima kao što su neurogeno mucanje i sindrom brzopletosti, sve veći broj istraživanja usmjeren je na definiranje kriterija za postavljanje dijagnoze. Napredak u znanosti brzo se odvija, stoga kliničari moraju biti u toku s najnovijim istraživanjima i spoznajama. Stoga je cilj ovog rada na temelju pregleda novije literature naglasiti diferencijalno dijagnostičke kriterije za navedene razvojne i stečene poremećaje tečnosti govora.

\section{MUCANJE DJECE}

U dječjoj dobi netečnosti u govoru mogu se pripisati normalnoj fazi u jezično-govornom razvoju, razvojnom mucanju ili neurogenom mucanju. Mnoga djeca u dobi između 2. i 5. godine prolaze kroz period netečnog govora koji nije mucanje već normalna netečnost govora (Guitar, 2006). Prema novijim istraživanjima, procjenjuje se da u predškolskoj populaciji 3,46\% djece muca, a u školskoj populaciji 0,83\% (Yairi i Seery, 2015). Također, u literaturi je zabilježen mali broj slučajeva kada su netečnosti kod djece bile rezultat nekog neurološkog oštećenja (Nass, Schreter, Heier, 1994; prema Theys i sur., 2011; Yeoh, Lind i Law, 2006; prema Theys i sur., 2009; Theys i sur., 2009). Neurogeno mucanje najčešće se povezuje s odraslim osobama stoga će detaljno biti opisano u poglavlju o mucanju odraslih osoba.

Kliničari se uglavnom slažu da razlikovanje normalne netečnosti i težih oblika mucanja ne predstavlja problem. Izazov u diferencijalnoj dijagnostici su granični slučajevi. Postavlja se pitanje koje su minimalne karakteristike netečnog govora kod vrlo blagog mucanja te koja je gornja granica koja određuje normalne netečnosti. Yairi i Seery (2015) navode sljedeće kriterije koji mogu olakšati razlikovanje razvojnog mucanja i normalne netečnosti u djece. Broj jedinica ponavljanja smatra se najvažnijom informacijom koja može olakšati razlikovanje početnog mucanja i normalne netečnosti (Ambrose i Yairi, 1999; prema Yairi i Seery, 2015). Ponavljanja koja sadrže 3 ili više jedinica ponavljanja (npr. ba-ba-ba-balon) karakteristična su za mucanje, dok su iznimno rijetka kod normalno tečne djece. Autori čak navode da su i 2 jedinice ponavljanja češće kod djece koja mucaju. Vremenske karakteristike ponavljanja također imaju dijagnostičku važnost. Ponavljanja djece koja mucaju značajno su brža u odnosu na djecu koja ne mucaju. Postojanje produžavanja duljih od 1 sekunde još je jedan snažan indikator mucanja. Broj mucajućih netečnosti u populaciji djece koja mucaju skoro je 10 puta veći u odnosu na djecu koja ne mucaju. Uvriježeni kriterij za razlikovanje mucanja od normalne netečnosti jest postojanje minimalno 3-4 mucajuće netečnosti na uzorku od 100 slogova/riječi (Yairi i Seery, 2015). Netečnosti koje karakteriziraju mucanje su ponavljanja slogova, jednosložnih riječi i dizritmična fonacija. Također, djeca koja mucaju proizvode 6 puta više grupiranih netečnosti koje se nazivaju clusteri (Manning, 2010). Sekundarna ponašanja su često prisutna kod početnog mucanja. Gotovo 50\% djece koja mucaju iskazuju napete pokrete dijelova tijela, posebice glave, lica ili vrata (Manning, 2010). Djeca s početnim mucanjem ne samo da iskazuju svjesnost o mucanju, već i negativne stavove o govoru u odnosu na uredno tečnu djecu (Manning, 2010). Osim podataka koji se dobiju direktnim promatranjem djeteta, klinički je značajan i podatak o postojanju mucanja u obitelji. Prema genetičkim istraživanjima mucanja, 30\%$60 \%$ osoba koje mucaju imaju pozitivnu obiteljsku anamnezu mucanja (Manning, 2010). Naposljetku, potrebno je uzeti u obzir i roditeljske opise i procjenu jakosti mucanja. Ako dijete tijekom procjene ne pokazuje mucajuća ponašanja a roditelji opisuju govor koji ukazuje na mogućnost postojanja mucanja, potrebno je snimiti uzorke govora kod kuće i analizirati ih. Istraživanja su pokazala da roditelji u velikom postotku ,postave“ dobru dijagnozu kada se radi o mucanju (Manning, 2010).

\section{MUCANJE ODRASLIH OSOBA}

Iako se najčešće javlja tijekom intenzivnog perioda usvajanja jezika i govora u djetinjstvu, mucanje se može prvi put pojaviti i u odrasloj dobi. Obično se dijeli na razvojno perzistentno i stečeno mucanje. S obzirom na etiologiju stečenog mucanja, razlikuje se neurogeno mucanje, psihogeno mucanje i mucanje uzrokovano lijekovima (Van Borsel, 2014). Najčešći oblik stečenog mucanja u odrasloj dobi je neurogeno mucanje (Van Borsel i Taillieu, 2001). Termin stečeno mucanje ponekad se pogreš- 
no koristi kao sinonim za neurogeno mucanje (Van Borsel, 2014). Neurogeno mucanje stečeni je poremećaj tečnosti govora koji obično pogađa odrasle osobe uslijed neurološkog oštećenja (Theys i sur., 2008; Ward, 2010). Kao najčešći uzroci neurogenog mucanja navode se moždani udar, traumatska oštećenja mozga, neurodegenerativne bolesti, tumori i korištenje narkotika (Manning, 2010; Theys i sur., 2008; Bloodstein i Bernstein Ratner, 2008). Podaci o etiologiji navode na zaključak kako se neurogeno mucanje ne može povezati isključivo s oštećenjem određenog dijela mozga već mogu biti zahvaćene različite neurološke strukture koje su dio neuralne mreže za proizvodnju tečnog govora (Van Borsel i Taillieu, 2001; Theys i sur., 2008; Ward, 2010). Psihogeno mucanje odnosi se na iznenadni početak mucanja u odrasloj dobi kojem prethodi značajan traumatski događaj (Ward, 2010). Uzroci variraju ali se svi povezuju s visokom razinom stresa $\mathrm{i} / \mathrm{ili}$ anksioznosti. Mucanje uzrokovano lijekovima (eng. drug-induced stuttering) podrazumijeva netečnosti koje su nuspojava korištenja različitih lijekova (Van Borsel, 2014). Mucanje uzrokovano lijekovima razlikuje se po pitanju uzroka, dijagnostike $\mathrm{i}$ primjerene intervencije. Za razliku od neurogenog mucanja, uzrok ove vrste mucanja može se otkloniti. Stoga postoje dobri argumenti koji idu u prilog stajalištu da je mucanje uzrokovano lijekovima zasebna kategorija stečenog mucanja (Van Borsel, 2014).

\section{Diferencijalna dijagnostika neurogenog $\mathbf{i}$ razvojnog mucanja}

Česta je dilema među stručnjacima predstavljaju li neurogeno i razvojno mucanje dva različita poremećaja tečnosti govora te na temelju kojih se diferencijalno dijagnostičkih kriterija mogu pouzdano razlikovati. Iako neurogeno i razvojno mucanje dijele neke zajedničke karakteristike, brojni autori predlažu kriterije za razlučivanje ovih poremećaja. Helm-Estabrooks (1999; prema Thyes i sur., 2008) navodi značajke koje se tradicionalno povezuju s neurogenim mucanjem:

1. Netečnosti se javljaju na sadržajnim i funkcionalnim riječima.

2. Govorniku smetaju netečnosti ali nije anksiozan.

3. Ponavljanja, produžavanja i blokade mogu se javiti na svim pozicijama u riječi.
4. Sekundarni simptomi nisu povezani s trenutcima netečnosti.

5. Nema adaptacijskog učinka (smanjenje netečnosti uslijed ponovljenog čitanja istog odlom$\mathrm{ka})$.

6. Mucanje se javlja na gotovo svim govornim zadacima.

Pod 6. kriterijem podrazumijeva se i korištenje uvjeta za poboljšanje tečnosti govora kao što su promijenjena povratna slušna sprega (AAF- Altered auditory feedback), pjevanje, zborno čitanje i ponovljeno čitanje (adaptacijski efekt) (Krishnan i Tiwari, 2013). Uvjeti za smanjenje netečnosti koji pripadaju promijenjenoj povratnoj slušnoj sprezi (AAF) su zakašnjela povratna slušna sprega (Delayed auditory feedback-DAF), frekvencijski izmijenjena povratna slušna sprega (Frequency altered feedback-FAF) i maskirana povratna slušna sprega (Masked altered feedback-MAF). Izostanak poboljšanja tečnosti u ovim uvjetima često se povezuje s neurogenim mucanjem i navodi kao jedan od kriterija u diferencijalnoj dijagnostici (Lundgren i sur., 2010; Manning, 2010). Novija su istraživanja pokazala da se navedeni kriteriji ne mogu koristiti kao pouzdani diferencijalno dijagnostički kriteriji jer osobe $\mathrm{s}$ neurogenim mucanjem predstavljaju izrazito heterogenu populaciju (Van Borsel i Taillieu, 2001; Jokel i sur., 2007; Theys i sur., 2008; Tani i Sakai, 2011 ).

\section{Diferencijalna dijagnostika neurogenog i psihogenog mucanja}

Diferencijalna dijagnostika neurogenog i psihogenog mucanja predstavlja izazov iz više razloga. Iako se radi o poremećajima relativno niske prevalencije, ovi poremećaji dijele neke zajedničke karakteristike. Prikupljanje anamnestičkih podataka iznimno je važno u procjeni stečenog mucanja. Baumgartner (1999, prema Manning, 2010) predlaže provođenje pažljivo planiranog intervjua s ciljem otkrivanja povezanosti između govornih problema, neurološkog oštećenja i mogućih stresnih događaja u životu klijenta. Na temelju anamnestičkih podataka važno je isključiti postojanje neuroloških oštećenja (Manning, 2010). Također, korisno je uzeti u obzir činjenicu da je pojavnost neurogenog mucanja veća u odnosu na psihogeno mucanje. Važno je naglasiti da mnogi slučajevi koji 
se u literaturi opisuju kao psihogeno mucanje imaju neurološku komponentu. Novije tehnologije funkcionalnog oslikavanja mozga mogu otkriti neurološke promjene u slučajevima stečenog mucanja koji se povezuju sa psihogenom etiologijom.

Diferencijalna dijagnostika neurogenog i psihogenog mucanja isključivo na temelju govorne simptomatologije nepouzdana je jer se simptomi uvelike preklapaju (Ward, 2010). Baumgartner i Duffy (1997; prema Lundgren i sur., 2010) navode da je brz učinak terapije najpouzdanije obilježje koje razlikuje ova dva poremećaja. Nepostojanje adaptacijskog efekta povezuje se s neurogenim i psihogenim mucanjem, ali pogoršanje tečnosti uslijed ponovljenog čitanja istog teksta smatra se snažnim indikatorom psihogenog mucanja (Baumgartner i Duffy, 1997; prema Manning, 2010). Upadljiva karakteristika psihogenog mucanja je i stereotipnost netečnosti, koja može izgledati kao da je osoba odabrala jedan obrazac netečnosti kojeg se drži (Manning, 2010). Duffy (2008; prema Ward, 2010) sugerira kako je u slučajevima neuspješne terapije psihogenog mucanja važno razmotriti prekid terapije, jer u suprotnom može doći do pogoršanja simptoma. Theys i sur. (2009) te Ward (2010) na temelju studija slučajeva upućuju na problematiku razlikovanja neurogenog i psihogenog mucanja. Ward (2010) navodi zaključak kako je donošenje kliničke odluke o dijagnozi problematično zbog nedovoljnog razumijevanja simptoma neurogenog mucanja i njihovog preklapanja sa simptomatologijom psihogenog mucanja.

Tablica 1. Razlikovne karakteristike neurogenog i psihogenog mucanja (Lundgren i sur., 2010)

\begin{tabular}{|l|c|c|}
\hline Karakteristike & $\begin{array}{c}\text { Neurogeno } \\
\text { mucanje }\end{array}$ & $\begin{array}{c}\text { Psihogeno } \\
\text { mucanje }\end{array}$ \\
\hline Nagli početak & + & + \\
\hline $\begin{array}{l}\text { Ponavljanja, produžavanja i } \\
\text { blokade na svim pozicijama u } \\
\text { riječi }\end{array}$ & + & - \\
\hline Prisutnost anksioznosti & - & + \\
\hline $\begin{array}{l}\text { Konzistentnost mucanja kroz } \\
\text { različite govorne zadatke } \\
\text { (spontani govor, čitanje, } \\
\text { ponavljanje) }\end{array}$ & + & + \\
\hline Sekundarna ponašanja & - & - \\
\hline Bizarna kvaliteta netečnosti & - & + \\
\hline $\begin{array}{l}\text { Simbolička značajnost } \\
\text { trenutnog poremećaja }\end{array}$ & - & + \\
\hline
\end{tabular}

\section{Diferencijalna dijagnostika neurogenog mucanja i drugih stečenih poremećaja komunikacije}

$\mathrm{Na}$ temelju pregleda literature, slučajevi neurogenog mucanja mogu se podijeliti u dvije kategorije. Jednu kategorije čine slučajevi kada je neurogeno mucanje udruženo s afazijom a drugu skupinu kada je udruženo s dizartrijom i apraksijom (Lundgren i sur., 2010). „Čisti slučajevi“ neurogenog mucanja potvrda su stajalištu da neurogeno mucanje predstavlja zaseban poremećaj, a ne popratni poremećaj nekog od stečenih poremećaja komunikacije (Bloodstein i Bernstein Ratner, 2008). Navedeni nalaz potvrđuje i istraživanje Theys i sur. (2011) koji navode 6 ispitanika s neurogenim mucanjem koji nisu imali pridružene jezično-govorne poremećaje. Postojanje drugih stečenih poremećaja komunikacije može otežati prepoznavanje neurogenog mucanja. Theys i sur. (2008) navode kako su njihovi ispitanici u velikom postotku (67\%) imali višestruke pridružene jezično-govorne poremećaje. Nadalje, Theys i sur. (2011) navode zaključak da veći broj pridruženih jezično-govornih poremećaja rezultira većom učestalošću netečnosti kod neurogenog mucanja ali broj pridruženih poremećaja ne predviđa perzistiranje mucanja tijekom vremena. Palilalija je još jedan stečeni poremećaj tečnosti govora koji je potrebno razlučiti od neurogenog mucanja. Van Borsel i sur. (2007) navode karakteristike koje su prisutne kod palilalije i razlikuju je od razvojnog $\mathrm{i}$ stečenog mucanja:

- Ponavljanja duljih jezičnih jedinica (riječi i fraza u odnosu na glasove i slogove).

- Ponavljanja mogu biti praćena smanjenom glasnoćom govora.

- Broj ponavljanja je mnogo veći, u nekim slučajevima do 50 puta.

- Ponavljanja se često odnose na finalne riječi i fraze u rečenici.

\section{DIFERENCIJALNA DIJAGNOSTIKA MUCANJA I SINDROMA BRZOPLETOSTI}

Sindrom brzopletosti prvi je put opisao njemački leksikograf Adolph Kussmanl 1877. godine (Weiss, 1964; prema Sardelić i Rendulić, 2012), ali do danas ne postoji općeprihvaćena definicija 
ovog poremećaja. U radnoj definiciji najmanjeg zajedničkog nazivnika St. Louis i Schulte (2011; str. 241-242) opisuju brzopletost kao ,poremećaj tečnosti čiji su segmenti konverzacije u govornikovom materinskom jeziku zamijećeni kao jako brzi, neregularni ili oboje. Segmenti brzog i/ili neregularnog govora moraju biti praćeni jednom ili više sljedećih karakteristika: (a) pretjeranim normalnim netečnostima, (b) pretjeranim skraćivanjem i brisanjem slogova i/ili (c) abnormalnim pauzama, naglascima ili govornim ritmom“". Poznato je da se brzopletost često udružuje s drugim poremećajima stoga je teško procijeniti koji su primarni simptomi brzopletosti a koji su dodatni. Diferencijalna dijagnostika brzopletosti i mucanja predstavlja izazov zbog toga što ti poremećaji imaju slične karakteristike i često koegzistiraju (Van Zaalen i sur., 2009a). Također, diferencijalna dijagnostika između brzopletosti i mucanja uglavnom se temelji na subjektivnoj kliničkoj procjeni logopeda. Upravo je cilj istraživanja Van Zaalen i sur. (2009a) bio razviti objektivne mjere procjene brzopletosti i mucanja te ih usporediti sa subjektivnim procjenama stručnjaka koji se bave poremećajima tečnosti. Rezultati ovog istraživanja pokazali su kako se postavljena dijagnoza temeljena na subjektivnim odlukama podudara s odlukama drugog stručnjaka u samo 50\% slučajeva. Kada su subjektivnim odlukama stručnjaka dodani podaci o omjeru netečnosti i rezultati ispitivanja govorno-motorne kontrole na razini riječi, postignuto je slaganje za $77,8 \%$ postavljenih dijagnoza. Ipak, za 15,2\% slučajeva ni tada nije postignuto slaganje među stručnjacima. U odnosu na tri glavne karakteristike sindroma brzopletosti, rezultati ovog istraživanja mogu se sumirati na sljedeći način:

- Brzina artikulacije nije se pokazala dijagnostički značajnom što se može objasniti odlukom da se analiziraju samo tečni iskazi dok su kod brzopletaša netečni iskazi upravo oni koje karakterizira brza artikulacija.

- Omjer netečnosti iznad 3 pokazao se kao dobar dodatni dijagnostički kriterij pri procjeni prepričavanja. Autori pretpostavljaju kako pri prepričavanju osobe koje su brzoplete ne prilagođavaju govornu brzinu složenijim jezičnim razinama što rezultira većom učestalošću običnih netečnosti.
- Pogreške artikulacijske preciznosti i glatkoće u Screening Pittige Articulatie testu-SPA (Van Zaalen i sur., 2009c) kojim se ispituje govorno-motorna kontrola na razini riječi pri povećanoj govornoj brzini mogu se smatrati indikatorima brzopletog ponašanja.

Van Zaalen i sur. (2009b) procijenili su valjanost liste provjere za procjenu sindroma brzopletosti (Predicitive Cluttering Inventory - PCI, Daly i Cantrell, 2006) kao instrumenta za utvrđivanje sindroma brzopletosti. Istraživanje je provedeno na uzorku od 137-ero djece u dobi od 10.6 do 12.1 godina. Autori su zaključili da PCI u sadašnjem obliku ne služi kao valjani dijagnostički instrument za procjenu sindroma brzopletosti. Može poslužiti za razlikovanje tečnih i netečnih govornika, ali ne i za razlikovanje poremećaja tečnosti. U Tablici 2. navedene su razlikovne karakteristike sindroma brzopletosti i mucanja u odnosu na različita područja komunikacije i kognicije (Scaler Scott, 2010).

Osim s mucanjem, sindrom brzopletosti često se udružuje i s poremećajem pažnje i/ili hiperaktivnim poremećajem (ADHD) te specifičnim teškoćama učenja. Brzopleta djeca često se opisuju kao nemirna, loših organizacijskih vještina, nezainteresirana za rad, impulzivnog ponašanja i otklonjive pažnje (Ward, 2006). Navedene karakteristike postaju mnogo uočljivije s djetetovim polaskom u školu jer se ondje susreće s mnoštvom zahtjeva i pravila koja se moraju poštivati. Djeca sa specifičnim teškoćama učenja postižu loš akademski uspjeh unatoč urednoj inteligenciji. Različiti jezično-govorni poremećaji mogu biti udruženi sa specifičnim teškoćama učenja a upravo je odnos brzopletosti i specifičnih teškoća učenja predmet interesa znanstvenika dugi niz godina (Van Zaalen i sur., 2011). Iako je jezično-govorna proizvodnja narušena kod oba poremećaja, pozadina tih problema se razlikuje. Kod djece sa specifičnim teškoćama učenja, narušena jezična proizvodnja primarno je rezultat teškoća leksičkog priziva koje dovode do narušene strukture rečenice i velikog broja običnih netečnosti (Van Zaalen i sur., 2011). Njihove su teškoće prisutne u svim jezičnim modalitetima te pri smanjenoj brzini govora. Suprotno tomu, jezično-govorna proizvodnja kod sindroma brzopletosti narušena je samo pri povećanoj brzini govora kada dolazi do nesrazmjera između njihovih 
Tablica 2. Razlikovne karakteristike mucanja i sindroma brzopletosti (Scaler Scott, 2010)

\begin{tabular}{|c|c|c|}
\hline SIMPTOMI & MUCANJE & BRZOPLETOST \\
\hline GDJE SU NAJVEĆI PROBLEMI? & Riječi, slogovi i glasovi & Poruka \\
\hline SVJESNOST O POREMEĆAJU & $\mathrm{Da}$ & Da i ne \\
\hline $\begin{array}{l}\text { POVEĆANA I/ILI } \\
\text { NEREGULARNA BRZINA } \\
\text { GOVORA }\end{array}$ & $\begin{array}{l}\text { Nije uobičajeno za mucanje ali je osoba } \\
\text { može koristiti kao sekundarnu strategiju } \\
\text { da izbjegne mucanje }\end{array}$ & $\begin{array}{l}\text { Da, obavezan simptom sindroma } \\
\text { brzopletosti (brzina govora može biti } \\
\text { prebrza i/ili neregularna, ne mora biti oboje) }\end{array}$ \\
\hline $\begin{array}{l}\text { VRSTA GOVORNIH } \\
\text { NETEČNOSTI }\end{array}$ & $\begin{array}{l}\text { Prevladavaju mucajuće netečnosti } \\
\text { (ponavljanja, produžavanja, blokade) }\end{array}$ & $\begin{array}{l}\text { Prevladavaju obične netečnosti (ubacivanja, } \\
\text { ispravljanja, ponavljanja fraza) }\end{array}$ \\
\hline PRIMJERI NETEČNOSTI & $\begin{array}{l}\text { Ponavljanja glasova i slogova: } \\
\text { t-t-ti, ku-ku-kuća } \\
\text { Produžavanja: zzzmija } \\
\text { Blokade: glas zapne i osoba ima teškoće } \\
\text { s prelaskom na drugi glas; P---etar } \\
\end{array}$ & $\begin{array}{l}\text { Ubacivanja: ovaj, ono, hmm, aha i sl. } \\
\text { Ponavljanja fraza: daj mi, daj mi } \\
\text { Ispravljanja: molim vas sladoled.Ne, ne, } \\
\text { ipak bih sok. }\end{array}$ \\
\hline ARTIKULACIJSKE TEŠKOĆE & Nisu prisutne kod „čistog“ mucanja & $\begin{array}{l}\text { Neprecizna artikulacija koja narušava } \\
\text { razumljivost govora }\end{array}$ \\
\hline PROZODIJA & Uredna & $\begin{array}{l}\text { Može biti narušena zbog kraćih pauza } \\
\text { uslijed povećane brzine govora }\end{array}$ \\
\hline $\begin{array}{l}\text { AFEKTIVNE I KOGNITIVNE } \\
\text { SASTAVNICE }\end{array}$ & $\begin{array}{l}\text { Izbjegavanje komunikacije i negativni } \\
\text { stavovi }\end{array}$ & Mogu postojati \\
\hline PRAGMATIKA & Uredna & Narušena \\
\hline
\end{tabular}

jezično-govornih sposobnosti i komunikacijskih zahtjeva (Van Zaalen i sur., 2011). Odnos sindroma brzopletosti i navedenih pridruženih poremećaja još uvijek nije dovoljno razjašnjen te su potrebna daljnja istraživanja.

\section{POREMEĆAJI TEČNOSTI GOVORA KOD GENETSKIH SINDROMA}

Određeni genetski sindromi povezuju se s postojanjem poremećaja tečnosti govora, ali znanje o njihovim karakteristikama netečnog govora još uvijek je ograničeno. Sindromi koji će biti opisani razlikuju se s obzirom na etiologiju i postojanje dodatnih poremećaja (prvenstveno intelektualnih teškoća). Uključeni su u ovaj prikaz jer za njih postoje dostupne informacije o govornim netečnostima.

\section{Downov sindrom}

Mucanje se navodi kao neobično česta pojava u populaciji osoba s Downovim sindromom, s prevalencijom između 15\% i 48\% (Bloodstein, 1995; prema Van Borsel i Tetnowski, 2007) dok je prevalencija mucanja u cjelokupnoj populaciji osoba s intelektualnim teškoćama oko 5\%. Bray (2003, http://www.stammering.org/speaking-out/ articles/nature-dysfluency-downs-syndrome) je provela istraživanje u kojem je 27 logopeda ispunilo upitnik o vrsti govornih netečnosti kod osoba s Downovim sindromom svih kronoloških dobi. Rezultati su pokazali da se najveći postotak netečnosti (gotovo 90\%) odnosi na mucajuće netečnosti. Ostale sličnosti Downovog sindroma i razvojnog mucanja koje se navode u literaturi su najčešće postojanje mucanja na okluzivima te najveća učestalost inicijalnih ponavljanja (Willcox, 1988; prema Van Borsel i Tetnowski, 2007). O postojanju sekundarnih ponašanja kod osoba s Downovim sindromom koje su netečne ne postoji ujednačeno mišljenje u literaturi (Van Borsel i Tetnowski, 2007). U istraživanju Bray (2003, http://www. stammering.org/speaking-out/articles/naturedysfluency-downs-syndrome) mali broj osoba s Downovim sindromom je pokazao svjesnost govornih netečnosti, što se može dovesti u vezu s razinom kognitivnog funkcioniranja. Postavlja se pitanje može li prisutnost ili odsutnost sekundarnih ponašanja kod osoba s Downovim sindromom poslužiti kao diferencijalno dijagnostički kriterij.

Neki autori sugeriraju kako netečan govor kod osoba s Downovim sindromom predstavlja brzopletost, a ne mucanje. Van Borsel i Vandermeulen (2008) su na temelju PCI-a (Daly i Cantrell, 2006; 
https://www.mnsu.edu/comdis/isad10/papers/ daly10/daly10.html ) ispunjenog od strane 26 logopeda željeli istražiti učestalost sindroma brzopletosti kod 76 osoba s Downovim sindromom (raspon dobi od 3.8 do 57.3 godine). Rezultati su pokazali da je $78.9 \%$ ispitanika zadovoljilo kriterij za postavljanje dijagnoze brzopletosti, dok ih je $17.1 \%$ zadovoljilo kriterij za postojanje mucanja i brzopletosti. Dobiveni postoci izrazito su visoki u usporedbi s nekim drugim istraživanjima (Preus, 1996: prema Van Borsel i Vandermeulen, 2008). Autori upozoravaju na mogućnost postojanja specifičnog obrasca netečnosti kod osoba s Downovim sindromom te na upitnu prikladnost korištenja PCI-a u ovoj kliničkoj populaciji. Odnos Downovog sindroma, mucanja i brzopletosti te mogućnost postojanja obrasca netečnosti specifičnog za ovaj sindrom još uvijek nisu dovoljno razjašnjeni.

\section{Fragilni X sindrom}

Postojanje jezično-govornih poremećaja često je u populaciji osoba s Fragilnim X sindromom (Van Borsel i sur., 2008), a netečan govor smatra se tipičnom karakteristikom ovog sindroma. Učestalost netečnosti kod osoba s Fragilnim X sindromom niža je od prevalencije kod Downovog sindroma i nešto viša u odnosu na autizam i nespecifične oblike intelektualnih teškoća (Van Borsel i Tetnowski, 2007). Brojni autori opisuju netečan govor osoba s Fragilnim X sindromom kao mucanje. Van Borsel i sur. (2008) su pokazali da obrazac netečnosti u ovoj populaciji nije identičan razvojnom mucanju te autori navode pet razlikovnih karakteristika. S obzirom na vrstu netečnosti, gotovo $70 \%$ netečnosti u ovom istraživanju odnosilo se na obične netečnosti, veći broj netečnosti zabilježen je na funkcionalnim riječima, dužina riječi nije se pokazala povezana s brojem netečnosti te su ponavljanja uglavnom bila jednostruka. Nadalje, učestalost netečnosti nije bila povezana s vrstom govornog zadatka. Karakteristike koje su u skladu s karakteristikama razvojnog mucanja su prevlast ponavljanja inicijalnih dijelova riječi i rečenice te veći broj netečnosti na konsonantima. Rhoads (1984; prema Van Borsel i Tetnowski, 2007) je na uzorku od 15 muškaraca s Fragilnim $X$ sindromom pronašao učestala ponavljanja finalnih dijelova riječi i rečenica. Ovaj neobičan obrazac netečnosti mogao bi biti dijagnostički značajan ali nije potvrđen $u$ drugim istraživanjima.

Karakteristike brzopletosti koje su prisutne kod ovog sindroma su brza i fluktuirajuća govorna brzina, postojanje „eksplozija govora“ (eng. speech bursts) i neprecizna artikulacija. Van Borsel i sur. (2008) nisu potvrdili postojanje brzog govora kod svojih 9 ispitanika. U istraživanjima Fragilnog $\mathrm{X}$ sindroma ne spominju se podaci o postojanju sekundarnih ponašanja.

\section{Prader-Willijev sindrom}

Jezično-govorni razvoj također odstupa u ovoj populaciji te nekoliko autora sugerira postojanje poremećaja tečnosti (Van Borsel i Tetnowski, 2007). Defloor i sur. (2000) proveli su istraživanje čiji je cilj bio detaljno istražiti učestalost, vrstu i distribuciju netečnosti u govoru 15 osoba s PraderWillijevim sindromom kronološke dobi od 9.9 do 20.0 godina. U govoru ispitanika zabilježene su obične i mucajuće netečnosti dok su najčešće vrste netečnosti bila ubacivanja $(52,58 \%) \mathrm{i}$ ispravljanja $(11,10 \%)$. Najveći broj netečnosti zabilježen na inicijalnoj poziciji u riječi i rečenici te veća učestalost netečnosti na sadržajnim riječima ukazuju na sličnosti s razvojnim mucanjem. Odsustvo sekundarnih ponašanja tijekom netečnog govora, veća učestalost običnih netečnosti u odnosu na mucajuće netečnosti, postojanje netečnosti u finalnoj poziciji u riječima i rečenicama te veća učestalost netečnosti na jednosložnim riječima karakteristike su koje nisu u skladu s tipičnim obrascem razvojnog mucanja i mogu pomoći u diferencijalnoj dijagnostici netečnosti u ovoj populaciji. Ovo istraživanje potvrđuje da je govor osoba s Prader-Willijevim sindromom često netečan te ima karakteristike koje su u skladu s razvojnim mucanjem i karakteristike koje odstupaju od tipičnog obrasca razvojnog mucanja. Potrebna su daljnja istraživanja koja će detaljno proučavati netečnosti u ovoj populaciji.

\section{Touretteov sindrom}

Ovaj sindrom često se uspoređuje i dovodi u vezu s razvojnim mucanjem. Osim postojanja govornih netečnosti, sličnosti Touretteovog sindroma i razvojnog mucanja koje se navode u literaturi 
su jaka genetska komponenta, veća učestalost kod muškaraca, variranje simptoma ovisno o komunikacijskoj situaciji, postojanje motoričkih tikova, opsesivno-kompulzivne karakteristike i hiperaktivnost (De Nil i sur., 2005). Potrebno je naglasiti da motorički tikovi, opsesivno-kompulzivne karakteristike i hiperaktivnost nisu stalne karakteristike mucanja. Tikovi kod Touretteovog sindroma prisutni su neovisno o govoru, dok se tikovi kod mucanja povezuju isključivo s momentima mucanja (Yairi i Seery, 2015). Iako je postojanje govornih netečnosti kod osoba s Touretteovim sindromom dobro dokumentirano, podaci o vrsti i učestalosti netečnosti nisu ujednačeni u literaturi. Nekoliko istraživanja bavilo se opisom netečnosti u govoru osoba s Touretteovim sindromom.

Van Borsel i Vanryckeghem (2000) istražili su učestalost i vrstu netečnosti u govoru 18 godišnjeg mladića s Touretteovim sindromom. Autori su zaključili da ispitanikov obrazac netečnosti više odgovara opisu brzopletosti a ne razvojnom mucanju. Tetnowski i Donaher (2003, http://www.mnsu. edu/comdis/isad6/papers/donaher6.html) procijenili su tečnost govora dvojice dječaka kronološke dobi 8 i 11 godina s dijagnozom Touretteovog sindroma. Simptomi u govoru jednog ispitanika karakteristični su za sindrom brzopletosti, dok simptomi drugog ispitanika odgovaraju neurogenom mucanju. Van Borsel i sur. (2004) istražili su govor dva dječaka (9.11 i 12.7 godina) i jedne djevojčice (12.2 godine) s Touretteovim sindromom kroz različite govorne zadatke. Rezultati ovog istraživanja sugeriraju da kod osoba s Touretteovim sindromom postoji specifičan obrazac netečnosti koji dijeli sličnosti s razvojnim mucanjem, brzopletošću i palilalijom, ali se po određenim karakteristikama od njih i razlikuje. De Nil i sur. (2005) detaljno su istražili učestalost i vrstu govornih netečnosti tijekom konverzacije i čitanja na uzorku od 69 djece (8 Ž, $61 \mathrm{M})$ s Touretteovim sindromom $\mathrm{u}$ dobi od 4 do 18 godina. U konverzaciji osoba $\mathrm{s}$ Touretteovim sindromom postojala je veća učestalost ,više tipičnih netečnosti“", tj. običnih netečnosti koja se pokazala statistički značajnom.

Rezultati navedenih istraživanja sugeriraju kako se netečnosti u govoru osoba s Touretteovim sindromom kvalitativno razlikuju od razvojnog mucanja. Veća učestalost običnih netečnosti, ponavljanja medijalnih i finalnih dijelova riječi te izostanak smanjenja netečnosti u uvjetima poboljšanja tečnosti govora predstavljaju važne podatke $\mathrm{u}$ diferencijalnoj dijagnostici. Navedene razlike $\mathrm{u}$ rezultatima istraživanja moguće je tumačiti u svjetlu nedovoljnog razlikovanja mucajućih i običnih netečnosti.

\section{Neurofibromatoza tip 1}

Nekoliko autora (Kohler, 1990; Solot i sur., 1990; prema Van Borsel i Tetnowski, 2007) navodi postojanje poremećaja tečnosti u ovoj populaciji, ali detaljni podaci o govornim netečnostima su oskudni. Cosyns i sur. (2010) proveli su istraživanje o postojanju govornih poremećaja kod osoba s Neurofibromatozom tipa 1 na temelju upitnika samoprocjene kojeg je ispunilo 60 ispitanika kronološke dobi od 4.5 do 61.3 godine. Rezultati su pokazali da je $65 \%$ ispitanika navelo prisutnost barem jednog govornog poremećaja. Osim postojanja artikulacijskih poremećaja, narušenog intenziteta glasa, problema s govornim disanjem i oštećenja sluha, 9.1\% ispitanika od njih 55 navelo je postojanje mucanja. Svi ispitanici koji su potvrdili postojanje mucanja kao simptom navode blokade u govoru, dok za druge vrste govornih netečnosti podaci nisu dostupni. Alivuotila i sur. (2010) su na uzorku od 62 ispitanika objektivnim mjerenjima potvrdili postojanje narušene fonacije i artikulacije u ovoj populaciji, ali nisu potvrdili postojanje mucanja ni kod jednog ispitanika.

U istraživanju Cosyns i sur. (2014) analizirana je učestalost i vrsta govornih netečnosti te govorna brzina na uzorku od 30 odraslih ispitanika (15 M, 15 Ž) s Neurofibromatozom tipa 1. Njihovi rezultati uspoređeni su s rezultatima 30 kontrolnih ispitanika izjednačenih po kronološkoj dobi i spolu. Statistički značajne razlike među ispitanicima postojale su s obzirom na govornu brzinu. Veća artikulacijska brzina, češće i duže pauze postojale su u govoru osoba s Neurofibromatozom tipa 1. Učestalost običnih i mucajućih netečnosti nije se statistički značajno razlikovala među skupinama. Veća učestalost običnih netečnosti u odnosu na mucajuće netečnosti zabilježena je u skupini osoba s Neurofibromatozom tipa 1. Na temelju dobivenih podataka i nalaza o postojanju neprecizne artikulacije (Alivuotila i sur., 2010), autori sugeriraju da 
obrazac netečnosti u ovoj populaciji više nalikuje brzopletosti, a ne razvojnom mucanju.

\section{Turnerov sindrom}

Smatra se da većina žena s ovim sindromom ima neku vrstu jezično-govornih odstupanja ali su te teškoće suptilne (Jung, 1989; prema Van Borsel i Tetnowski, 2007). Istraživanje Van Borsel i sur. (1999; prema Van Borsel i Tetnowski, 2007) na uzorku od 128 žena s Turnerovim sindromom pokazalo je da je njih $24 \%$ u sadašnjosti ili prošlosti bilo uključeno u logopedsku terapiju zbog jezično-govornih teškoća. Mucanje je zabilježeno u 4 slučaja (3.1\%). Pregledom dostupne literature nisu pronađeni podaci o učestalosti i prirodi govornih netečnosti kod ovog sindroma. Potrebna su istraživanja koja će detaljno analizirati učestalost, vrstu i distribuciju govornih netečnosti kod Turnerovog sindroma.

\section{POREMEĆAJI TEČNOSTI GOVORA KOD OSOBA S PARKINSONOVOM BOLESTI}

Netečnosti u govoru su često navođeno obilježje Parkinsonove bolesti. U istraživanjima se navode ponavljanja slogova, zvučne i bezvučne blokade, produžavanja glasova, ponavljanja višesložnih riječi, ispravljanja, ubacivanja (Goberman i Blomgren, 2003; Goberman i sur., 2010; Sardelić i Farago, 2012). Budući da se kod Parkinsonove bolesti radi o netečnostima neurogenog a ne razvojnog podrijetla (Goberman i sur., 2010), razumno je pretpostaviti da će dijeliti više sličnosti s neurogenim, a ne s razvojnim mucanjem. Međutim, istraživanja naglašavaju sličnosti s razvojnim mucanjem.

Goberman i sur. (2010) istražili su učestalost i vrstu netečnosti na uzorku od 32 osobe $\mathrm{s}$ Parkinsonovom bolesti kroz zadatke čitanja i spontanog govora. Na temelju visoke učestalosti mucajućih netečnosti te veće učestalosti netečnosti u spontanom govoru u odnosu na zadatak čitanja autori zaključuju o sličnosti s razvojnim mucanjem. Sardelić i Farago (2012) ispitale su tečnost govora i kvalitetu glasa kod 55 godišnje ispitanice $\mathrm{s}$ Parkinsonovom bolesti kroz spontani govor, čitanje i prepričavanje. Osnovne karakteristike netečnog govora ispitanice su zastoji na inicijalnim glasovima i produžavanja vokala. Autorice zaključuju da klinička slika više odgovara razvojnom a ne neurogenom mucanju te da netečnosti ukazuju na motorički bazirano oštećenje. Nalaz o većoj učestalosti ukupnog broja netečnosti i mucajućih netečnosti u populaciji osoba s Parkinsonovom bolesti u odnosu na kontrolnu skupinu potvrđen je i u istraživanju Brabo i sur. (2014) na uzorku od 30 ispitanika s Parkinsonovom bolesti.

Pojedine studije istraživale su učinak farmakoloških terapija na učestalost netečnosti u govoru osoba s Parkinsonovom bolesti. Istraživanja se prvenstveno odnose na najčešće korišteni lijek levodopa koji povećava razinu dopamina u bazalnim ganglijima. Rezultati su kontradiktorni te neki ukazuju na smanjenje netečnosti uslijed korištenja levodope (Leder, 1996; Koller, 1983; prema Goberman i Blomgren, 2003), dok drugi ukazuju na povećanu učestalost netečnosti (Louis i sur., 2001; prema Goberman i Blomgren, 2003). Poremećaji glasa i govora kod Parkinsonove bolesti često se javljaju prije tjelesnih simptoma (Sardelić i Farago, 2012), koji se pak javljaju tek nakon što propadne 50\%-60\% dopaminergičkih neurona u supstanciji nigri (Demarin i Trkanjec, 2008). Upravo procjena glasa i govora u okviru logopedske dijagnostike ima značajnu ulogu u ranom otkrivanju bolesti i pravovremenom započinjanju terapije s ciljem usporavanja bolesti (Sardelić i Farago, 2012).

\section{ZAKLJUČAK}

Pregledom dosadašnjih istraživanja o diferencijalnoj dijagnostici poremećaja tečnosti govora kod navedenih poremećaja, stanja i oboljenja, doneseni su sljedeći zaključci.

Glavne razlikovne karakteristike normalne netečnosti i razvojnog mucanja su učestalost netečnosti, vrsta netečnosti i broj jedinica ponavljanja. Yairi i Ambrose (2005; prema Yairi i Seery, 2015) navode objektivnije kriterije koji mogu pomoći kliničaru u donošenju odluke muca li dijete ili je normalno tečno. Ova odluka je iznimno važna jer određuje način primjerene intervencije. O neurogenom mucanju djece postoji mali broj istraživanja stoga se kliničari u dijagnostici oslanjaju na kriterije uvriježene za neurogeno mucanje odraslih te dodatnu neurološku i psihološku obradu.

Diferencijalna dijagnostika neurogenog i psihogenog mucanja isključivo na temelju govorne 
simptomatologije nepouzdana je jer se simptomi uvelike preklapaju. U nekim slučajevima teško je procijeniti je li nastala netečnost rezultat neurološkog oštećenja ili psihološke reakcije na nastalo oštećenje.

Nedostatak podataka o prevalenciji i incidenciji, složena simptomatologija i postojanje pridruženih jezično-govornih poremećaja poput afazije, dizartrije, apraksije i palilalije, otežava postavljanje dijagnoze neurogenog mucanja i uzrok je niske razine svjesnosti o ovom poremećaju. Istraživanje Theys i sur. (2011) opovrgava uvriježeno mišljenje o neurogenom mucanju kao poremećaju niske incidencije, barem u podskupini osoba s moždanim udarom. Iako neurogeno mucanje nakon moždanog udara nije često kao afazija i dizartrija, važno je da kliničari, posebice logopedi, imaju na umu mogućnost postojanja neurogenog mucanja pri procjeni jezično-govornih sposobnosti osoba koje su pretrpjele moždani udar. Osobe s neurogenim mucanjem predstavljaju izrazito heterogenu skupinu u pogledu etiologije, simptomatologije i postojanja teškoća. Diferencijalna dijagnostika razvojnog i neurogenog mucanja oslanja se na tradicionalne kriterije čija opravdanost nije potvrđena nekim novijim istraživanjima. Važno je naglasiti da su istraživanja neurogenog mucanja metodološki neujednačena (mali broj ispitanika, različiti isključujući kriteriji, različita etiologija, načini računanja netečnosti, različiti govorni zadaci) stoga je generalizacija zaključaka ograničena. Potrebna su daljnja istraživanja koja će sistematično analizirati govorne i negovorne karakteristike osoba s neurogenim mucanjem na većim uzorcima ispitanika. Budući da klinička slika ovisi o mjestu oštećenja, u istraživanjima je potrebno slučajeve neurogenog mucanja grupirati prema neuropatologiji u podlozi. Također, sugerira se korištenje fMRI-a u svrhu otkrivanja neuralnih korelata različite izvedbe osoba s razvojnim i neuorogenim mucanjem u različitim govornim zadacima.

Da bi se sindrom brzopletosti mogao uspješno razlučiti od drugih jezično-govornih poremećaja, logopedska procjena mora obuhvatiti različite aspekte komunikacije i kognicije. Diferencijalna dijagnostika brzopletosti i mucanja predstavlja izazov zbog toga što ti poremećaji imaju slične karak- teristike i često koegzistiraju. Do sada se procjena temeljila na subjektivnim procjenama logopeda ali posljednjih godina postoji tendencija uspostavljanja objektivnih normi koje će olakšati donošenje kliničkih odluka.

Nedovoljan broj informacija je dostupan o poremećajima tečnosti govora kod genetskih sindroma u odnosu na druge aspekte komunikacije, a one informacije koje su dostupne su nedovoljno razjašnjene. Nameće se zaključak da ni jedan od navedenih sindroma nema obrazac netečnosti koji u potpunosti odgovara razvojnom mucanju. Razlike u tečnosti govora kod različitih sindroma mogu biti rezultat varijabli kao što su dob, spol, stupanj intelektualnih teškoća i postojanje dodatnih jezično-govornih teškoća. Postavlja se pitanje odgovara li netečan govor kod genetskih sindroma obrascu razvojnog mucanja, brzopletosti, koegzistiranju mucanja i brzopletosti ili postoji govorni obrazac specifičan za pojedine sindrome (Van Borsel i Tetnowski, 2007). Potrebna su daljnja istraživanja koja će uključivati veće uzorke ispitanika, dobro kontrolirane varijable te detaljnu analizu govornih i negovornih karakteristika u različitim govornim zadacima.

Iako je općeprihvaćena činjenica da osobe s Parkinsonovom bolesti proizvode mucajuća ponašanja i da su netečnosti pod utjecajem levodope, specifične karakteristike mucajućeg ponašanja nisu dovoljno istražene (Goberman i sur., 2010). Postavlja se pitanje jesu li njihove netečnosti usporedive s razvojnim mucanjem te mogu li se rezultati istraživanja Parkinsonove bolesti primijeniti na razvojno mucanje. Istraživanja koja potvrđuju sličnosti razvojnog mucanja i netečnosti kod Parkinsonove bolesti idu u prilog hipotezi o ulozi bazalnih ganglija u razvojnom mucanju.

Budući da diferencijalna dijagnostika poremećaja tečnosti još uvijek predstavlja veliki izazov u području logopedije, ovaj rad koji se temelji na novijim znanstvenim spoznajama može poslužiti kliničarima kao orijentir u dijagnostičkom postupku. Različiti poremećaji zahtijevaju različite terapijske postupke stoga je postavljanje točne dijagnoze temelj planiranja i provođenja uspješne intervencije. 


\section{LITERATURA}

Alivuotila, L., Hakokari, J., Visnapuu, V., Horpijaakko-Huuhka, A-M., Aaltonen, O., Happonen, R-P., Peltonen, S., Peltonen, J. (2010): Speech Characteristics in Neurofibromatosis Type 1, American Journal of Medical Genetics Part A, 152A, 42-51.

Bloodstein, O., Bernstein Ratner, N. (2008): A handbook on stuttering (Sixth edition). Thomson: Delmar learning.

Brabo, N. C., Minett, T. S., Ortiz, K. Z. (2014): Fluency in Parkinson's disease: disease duration, cognitive status and age, Arquivos de Neuro-Psiquiatria, 72(5), 349-355.

Bray, M. (2003): The nature of dysfluency in Down's syndrome. Posjećeno 10.10.2015. na mrežnoj stranici: http:// www.stammering.org/speaking-out/articles/nature-dysfluency-downs-syndrome.

Cosyns, M., Vandeweghe, L., Mortier, G., Janssens, S., Van Borsel, J. (2010): Speech disorders in neurofibromatosis type 1: a sample survey, International Journal of Language \& Communication Disorders, 45(5), 600-607.

Cosyns, M., Van Zaalen, Y., Mortier, G., Janssens, S., Amez, A., Van Damme, J. (2014): Disfluency: it is not always stuttering, Clinical genetics, 85, 298-299.

Daly, D. A., Cantrell, R. P. (2006): Cluttering: Characteristics labelled as diagnostically significant by 60 fluency experts, Paper presented at the 6th IFA World Congress on disorders of fluency, Dublin, Ireland. Posjećeno 7.12.2105. na mrežnoj stranici: https://www.mnsu.edu/comdis/isad10/papers/daly10/daly10.html.

Defloor, T., Van Borsel, J., Curfs, L. (2000): Speech fluency in Prader-Willi syndrome, Journal of Fluency Disorders, $25,85-98$.

Demarin, V., Trkanjec, Z. (2008): Neurologija za stomatologe. Zagreb: Medicinska naklada.

De Nil, L. F., Sasisekaran, J., Van Lieshout, P. H. H. M., Sandor, P. (2005): Speech disfluencies in individuals with Tourette syndrome, Journal of Psychosomatic Research, 58, 97-102.

Goberman, A. M., Blomgren, M. (2003): Parkinsonian speech disfluencies: effects of L-dopa-related fluctuactions, Journal of Fluency Disorders, 28, 55-70.

Goberman, A. M., Blomgren, M., Metzger, E. (2010): Characteristics of speech disfluency in Parkinson disease, Journal of Neurolinguistics, 23, 470-478.

Guitar, B. (2006): Stuttering An Integrated Approach to Its Nature and Treatment (Third Edition). Lippincott Williams \& Wilkins.

Jokel, R., De Nil, L. F., Sharpe, A. K. (2007): Speech disfluencies in adults with neurogenic stuttering associated with stroke and traumatic brain injury, Journal of Medical Speech-Language Pathology, 15(3), 249-257.

Krishnan, G., Tiwari, S. (2013): Differential diagnosis in developmental and acquired neurogenic stuttering: Do fluency-enhancing conditions dissociate the two?, Journal of Neurolinguistics, 26, 252-257.

Lundgren, K., Helm-Estabrooks, N., Klein, R. (2010): Stuttering following acquired brain damage: A review of the literature, Journal of Neurolinguistics, 23, 447-454.

Manning, W. H. (2010): Clinical Decision Making in Fluency Disorders (Third edition). Delmar cengage Learning: International Edition.

Sardelić, S., Brestovci, B., Heđever, M. (2001): Karakteristične razlike između mucanja i drugih poremećaja fluentnosti govora, Govor, 18, 45-60.

Sardelić, S., Farago, E. (2012): Procjena govora i glasa kod bolesnice oboljele od Parkinsonove bolesti, Hrvatska revija za rehabilitacijska istraživanja, 48(2), 98-108.

Sardelić, S., Rendulić, A. (2012): Sindrom brzopletosti: prepoznavanje i razlučivanje. Čovjek i govor, znanstveno stručna monografija VII. Međunarodnog simpozija verbotonalnog sistema (str. 443-457). Zagreb: Poliklinika SUVAG. 
Scaler Scott, K. (2010): Stuttering vs. Cluttering Brochure. National Stuttering Association. Posjećeno 2.12.2015. na mrežnoj stranici https://www.z2systems.com/neon/resource/nsa/File/Brochures/StuttervsClutter.pdf .

St. Louis, K. O., Schulte, K. (2011): Defining cluttering: the lowest common denominator. U Ward, D. i Scaler Scott, K. (ur.): Cluttering: A Handbook of Research, Interevtion and Education. (str. 233-253). New York: Psychology Press.

Tani, T., Sakai, Y. (2011): Analysis of five cases with neurogenic stuttering following brain injury in the basal ganglia, Journal of Fluency Disorders, 33, 1-23.

Tetnowski, J., Donaher, J. (2003): Disfluency Associated with Tourette's Syndrome: Two Case Studies. Posjećeno 30.9.2015. na mrežnoj stranici http://www.mnsu.edu/comdis/isad6/papers/donaher6.html.

Theys, C., Van Wieringen, A., De Nil, L. F. (2008): A clinician survey of speech and non-speech characteristics of neurogenic stuttering, Journal of Fluency Disorders, 33, 1-23.

Theys, C., Van Wieringen, A., Tuyls, L., De Nil., L. (2009): Acquired stuttering in a 16-year-old boy, Journal of Neurolinguistics, 22, 427-435.

Theys, C., Van Wieringen, A., Sunaert, S., Thijs, V., De Nil, L. F. (2011): A one year prospective study of neurogenic stuttering following stroke: incidence and co-occuring disorders, Journal of Communication Disorders, 44, 678-687.

Van Borsel, J., Vanryckeghem, M. (2000): Dysfluency and phonic tics in Tourette syndrome: A case report, Journal of Communication Disorders, 33, 227-240.

Van Borsel, J., Taillieu, C. (2001): Neurogenic stuttering versus developmental stuttering: An observer judgement study, Journal od Communication Disorders, 34, 385-395.

Van Borsel, J., Goethals, L., Vanryckeghem, M. (2004): Disfluency in Tourette syndrome: Observational study in three cases, Folia Phoniatrica et Logopaedica, 56, 358-366.

Van Borsel, J., Bontinck, C., Coryn, M., Paemeleire, F., Vandemaele, P. (2007): Acoustic features of palilalia: A case study, Brain and Language, 101, 90-96.

Van Borsel, J., Tetnowski, J. A. (2007): Fluency disorders in genetic syndromes, Journal of Fluency Disorders, 32, 279-296.

Van Borsel, J., Vandermeulen, A. (2008): Cluttering in Down Syndrome, Folia Phoniatrica et Logopaedica, 60, 312-317.

Van Borsel, J., Dor, O., Rondal, J. (2008): Speech fluency in fragile X syndrome, Clinical Linguistics \& Phonetics, 22(1), 1-11.

Van Borsel, J. (2014): Acquired stuttering: A note on terminology, Journal of Neurolinguistics, 27, 41-49.

Van Zaleen, Y., Wijnen, F., Dejonckere, P. H. (2009a): Differential diagnostic characteristics between cluttering and stuttering - Part one, Journal of Fluency Disorders, 34, 137-146.

Van Zaleen, Y., Wijnen, F., Dejonckere, P. H. (2009b): Differential diagnostic characteristics between cluttering and stuttering - Part two, Journal of Fluency Disorders, 34, 146-154.

Van Zaleen, Y., Wijnen, F., Dejonckere, P. H. (2009c): A test on speech motor control on word level, the SPA test, International Journal of Speech and Language Pathology, 11(1), 26-33.

Van Zaalen, Y., Wijnen, F., Dejonckere, P. H., (2011): Cluttering and learning disabilities. U Ward, D., Scaler Scott, K. (ur.): Cluttering: A Handbook of Research, Intervention and Education. (str. 100-114). New York: Psychology Press.

Ward, D. (2006): Stuttering and Cluttering: Frameworks for understanding and treatment. Hove and New York: Psychology Press. Taylor \& Francis Group.

Ward, D. (2010): Sudden onset stuttering in an adult: Neurogenic and psychogenic perspectives, Journal of Neurolinguistics, 23, 511-517.

Yairi, E., Seery, C. H. (2015): Stuttering: Foundations and Clinical Applications (Second edition). Pearson Education Limited. 


\section{DIFFERENTIAL DIAGNOSIS OF FLUENCY DISORDERS}

Abstract: Differential diagnosis refers to the identification of a disorder and its differentiation from other disorders with common symptoms. In the field of fluency disorders, disfluencies are a common symptom that can be part of different developmental and acquired disorders such as developmental stuttering, neurogenic stuttering, psychogenic stuttering, cluttering, aphasia, dysarthria, apraxia, palilalia, Parkinson disease and different genetic syndromes, specifically Down syndrom, Fragile X syndrome, PraderWilli syndrome, Tourette syndrome, Neurofibromatosis type I, and Turner syndrome.

In this paper, recent literature related to the differential diagnosis of listed fluency disorders is reviewed. Their general and specific symptomatology is described, and differential diagnostic criteria are highlighted. Because differential diagnosis of fluency disorders is still a challenge for speech and language therapists, this paper provides guidelines for clinical decision making. Accurate diagnosis is necessary to ensure the optimal therapy plan because different strategies are appropriate for different disorders. There are various limitations of research studies in this field, and many of them consist of case studies. Further systematic studies on large groups, with detailed descriptions of speech and non-speech characteristics across various types of speech tasks, are necessary in order to obtain a better understanding of different fluency disorders.

Keywords: differential diagnosis, fluency disorders, developmental disorders, acquired disorders 